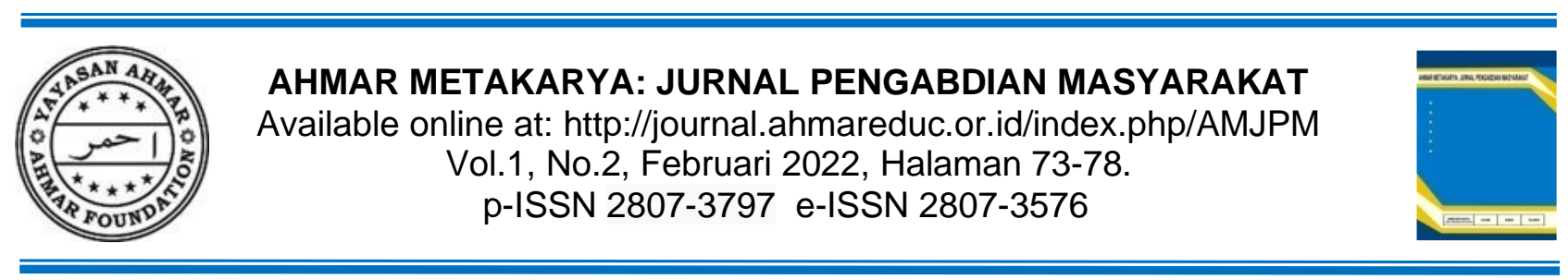

\title{
Pemeriksaan Kesehatan Gratis Pada Masyarakat Di Masa Pandemi COVID-19
}

\author{
Desria Mauliati \\ Akademi Kebidanan Saleha, Banda Aceh, Indonesia \\ ${ }^{*}$ E-mail: desria.stafsaleha88@gmail.com
}

Received: 29 Januari 2022

Accepted: 25 Februari 2022

Published: 28 Februari 2022

\begin{abstract}
The behavior of clean and healthy living in the community before the COVID-19 pandemic was still low, which consisted of the habit of washing hands with soap, consuming healthy food, physical activity, adequate rest, clean water, proper sanitation, not smoking, and others. When the covid-19 pandemic occurred, Indonesian people who had various social characteristics, ranging from age group, education level, economic status, exposure to the internet/mass media, social environment, culture, ethnicity and others had diverse understandings and attitudes towards the Covid-19 pandemic, the understanding and attitudes formed can affect the actions/behavior of the community, not all community members comply with the health protocol. The health problem that often occurs in the local community is that hypertension is a public health threat because of its potential to cause complications such as stroke, coronary heart disease and kidney failure. The purpose of this service is to increase community compliance with health protocols and to find out the results of blood pressure checks in order to prevent and treat these health problems. The method used in this activity is by giving announcements and gathering the community in the meunasah yard of le Suum Village and immediately holding free health checks for 23 people who come. The result of this service is that it is carried out properly and smoothly in accordance with the activity plan that has been prepared, this activity received a very good response from the community with the activeness and presence of the community to take part in the free health check-up activity by not leaving the activity before the end of time. It is hoped that after this activity the community can realize the importance of maintaining health, especially as a preventive program from health problems that occur especially during the Covid-19 pandemic.
\end{abstract}

Keywords: Health Checkup, Hypertension, Covid-19 pandemic.

\begin{abstract}
Abstrak
Perilaku hidup bersih dan sehat pada masyarakat sebelum pandemi covid-19 masih rendah, yaitu terdiri dari kebiasaan cuci rangan memakai sabun, konsumsi makanan sehat, aktivitas fisik, istirahat yang cukup, air bersih, sanitasi layak, tidak merokok, dan lain-lain. Ketika pandemi covid-19 terjadi, masyarakat indonesia yang memiliki karakteristik sosial yang beragam, mulai dari kelompok usia, taingkat pendidikan, status ekonomi, terpapar internet/ media masa, lingkungan sosial, budaya, suku dan lain-lain memiliki pemahaman dan sikap yang beragam terhadap pandemi Covid-19, pemahaman dan sikap yang terbentuk dapat mempengaruhi tindakan/perilaku masyarakat, tidak semua anggota masyarakat patuh pada protokol kesehatan. Masalah kesehatan yang banyak terjadi di masyarakat setempat adalah hipertensi menjadi salah satu ancaman kesehatan masyarakat karena potensinya yang sangat mampu mengakibatkan kondisi komplikasi seperti stroke, penyakit jantung coroner dan gagal ginjal. Tujuan pengabdian ini adalah untuk meningkatkan kepatuhan masyarakat terhadap protokol kesehatan dan untuk mengetahui hasil pemeriksaan tekanan darah dalam rangka mencegah dan mengobati masalah kesehatan tersebut. Adapun metode yang digunakan dalam kegiatan ini adalah dengan cara memberikan pengumuman dan mengumpulkan masyarakat dihalaman meunasah Desa le Suum dan langsung mengadakan pemeriksaan kesehatan gratis kepada 23 orang yang datang. Kegiatan ini diharapkan berjalan dengan baik dan lancar sesuai dengan rencana kegiatan yang telah disusun, kegiatan ini mendapatkan sambutan yang sangat baik dari masyarakat
\end{abstract}


dengan keaktifan dan kehadiran masyarakat untuk mengikuti kegiatan pemeriksaan kesehatan gratis dengan tidak meninggalkan kegiatan sebelum waktu berakhir. Diharapkan setelah dilakukan kegiatan ini masyarakat dapat menyadari pentingnya menjaga kesehatan terutama sebagai program prefentif dari masalah kesehatan yang terjadi terutama di masa pandemi Covid-19.

Kata Kunci: Pemeriksaan Kesehatan, Hipertensi, Pandemi Covid-19.

\section{A. PENDAHULUAN}

World Health Organization (WHO) pada tahun 2020 menerjemahkan virus corona sebagai virus yang akan mengakibatkan flu bisa hingga penyakit yang lebih parah seperti sindrom pernapasan timur tengah (MERS-CoV) dan sindrom pernafasan akut parah (SARS-CoV). WHO memberikan enam kriteria new normal, yaitu (1) penularan covid-19 sudah terkendali, (2) system kesehatan dapat mendeteksi, menguji, mengisolasi, melacak kasus dan mengkarantina pasien covid-19, (3) resiko penularan dapat dikurangi terutama, di tempat dengan kerentanan tinggi seperti panti jompo, fasilitas kesehatanmental dan tempat keramaian, (4) upaya pencegahan di lingkungan kerja seperti jaga jarak fisik, fasilitas cuci tangan, serta etika saat bersin dan batuk, (5) pencegahankasus Covid-19 dari luar negeri serta (6) himbauan masyarakat untuk berpartisipasi dalam masa transisi new normal (WHO, 2021).

Hipertensi merupakan penyakit yang tidak menular yang menjadi salah satu penyebab utama kematian di dunia, Organisasi (WHO) mengestinasikan saat ini prevalensi hipertensi secara global sebesar $22 \%$ dari total penduduk dunia, Dari sejumlah penderita tersebut, hanya kurangdari seperlima yang melakukan upaya pengendalian terhadap tekanan darah yang dimiliki (WHO, 2021). Menurut $\mathrm{WHO}$, wilayah Afrika memiliki prevalensi hipertensi tertinggi sebesar $27 \%$ Asia Tenggara berada di posisi ketiga tertinggi dengan prevalensi sebesar $25 \%$ terhadap total penduduk, WHO juga memperkirakan 1 di antara 5 orang perempuan di seluruh dunia meimiliki hipertensi, jumlah ini lebih besar di antara kelompok laki-laki yaitu 1 diantara 4 . Peningkatan prevalensi hipertensi berdasarkan carapengukuran juga terjadi di hampir seluruh provinsi Indonesia, peningkatan prevalensi tertinggi terdapat di provinsi indonesnia. Peningkatan prevalensi tertinggi terdapat di provinsi DKI Jakarta sebesar 13,4\%, Kalimantan selatan sebesar 13,3\% dan Sulawesi Barat Sebesar 12,3\% (Kemenkes RI, 2021).

Berdasarkan Riskesdas Aceh (2021), Revalensi hipertensi berdasarkan hasil pengukuran pada penduduk umur > 18 tahun, terdapat 3 kabupaten/kota di provinsi aceh dengan kasus hipertensi tertinggi yaitu kabupaten Bener Meriah sebesar 36,075 dan Aceh tamiang 34,97\%. Hipertensi menjadi salah satu ancaman kesehatan masyarakat karena potensinya yang sangat mampu mengakibatkan kondisi komplikasi seperti stroke, penyakit jantung coroner, dan gagal ginjal. Penegakkan diagnose dapat dilakukan melalui pengukuran tekanan darah. Hipertensi di tandai dengan hasil pengukuran tekanan darah yang menunjukkan tekanan sistolik sebesar > 140 $\mathrm{mmHg}$ atau dan tekanan diastolik> $90 \mathrm{mmHg}$ (Wijayakusuma, 2006). Hipertensi dapat dicegah dengan mengendalikan perilaku beresiko seperti merokok, diet yang tidak sehat, seperti kurang konsumsi sayur dan buah serta konsumsi gula, garam dan lemak berlebihan, obesitas, kurang aktifitas fisik, konsumsi alkohol yang berlebihan dan stress (Kemenkes, RI, 2021).

Diagnosis hipertensi ditegakan apabila kenaikan tekanan darah ini bersifat menetap pada pemeriksaan ulang dalam waktu 1-2 minggu. Menanyakan beraoa lama, riwayat penyakit, riwayat minum obat, riwayat penyakit jantung, riwayat kelurga VII (Ahmad, 2011).

Dilakukan dengan mengukur tekanan darah pada kedua lengan sebanyak dua kali atau lebih dengan interval 1-2 minggu. Berdasarkan JNC (The Joint Committee on Detection, Evaluation and Treatment of high blood pressure) (Sutanto, 2010).

\begin{tabular}{lcccc}
\hline Klarifikasi & Sistolik & & Diastolik & Perubahan Gaya hidup \\
\hline Normal & $>120$ & dan & $<80$ & Pertahankan \\
Pre-Hipertensi & $120-139$ & dan & $80-89$ & + \\
Hipertensi Tingk. I & $140-159$ & dan & $90-99$ & ++ \\
Hipertensi Tingk. II & $>160$ & dan & $>100$ & +++ \\
\hline
\end{tabular}


Tujuan pengabdian ini adalah untuk meningkatkan kepatuhan masyarakat terhadap protokol kesehatan dan untuk mengetahui hasil pemeriksaan tekanan darah dalam rangka mencegah dan mengobati masalah kesehatan tersebut.

\section{B. METODE DAN PELAKSANAAN}

Metode yang digunakan dalam pengabdian masyarakat ini yaitu mengadakan pemeriksaan kesehatan gratis di masa pandemi covid-19 dengan melalui berbagai tahapan kegiatan,antara lain:

1. Tahap Persiapan

Adapun tahapan persiapan (pra planning), yaitu antara lain:

a. Mempersiapkan tempat/lokasi pelaksanaan pemeriksaan

b. Mempersiapkan masyarakat secara antrian dengan mengikuti protokol kesehatan yaitu memakai masker, mencuci tangan, mengatur jarak, Menjauhi kerumunan dan membatasii mobilisasi dan interaksi.

c. Melakukan pendataan pasien yang datang berkunjung.

d. Melakukan pengukuran Suhu tubuh.

e. Mempersiapkan alat-alat yang dilakukan dengan prinsip steril, bersih, aman dan nyaman

f. Membuat Pendokumentasian Kegiatan

2. Tahap Pelaksanaan

Kegiatan ini dilksanakan untuk peduli dalam menurunkan angka kesakitan dan meningkatkan status kesehatannya serta mencegah hipertensi dimasa pandemi covid-19 dengan pemeriksaan kesehatan gratis, obat serta jasa konsultaasi. Kgitaan ini di laksanakan selama 1 hari yaitu pada hari selasa, tangga 9 Maret 2021.

3. Tahap Evaluasi

a. Struktur

Peserta yang hadir adalah semua masyarakat Desa le Suum yang telah mendapatkan informasi sebelumnya untuk dapat hadir di perkarangan menasah desa guna mengikuti kegiatan pemeriksaan kesehatan gratis diantaranya pemeriksaan Tekanan darah, pemeriksaan glukosa darah sesuai dengan rencana yang dibuat dan perlengkapan yang dilakukan untuk pelaksanaan kegiatan tersebut sebagimana mestinya.

b. Proses

Pelaksanaan kegiatan dalam pengabdian masyarakat ini akan berlangsung selama 1 hari ditanggal 09 Maret 2021 dari pukul 09.00 s/d 14.00 WIB sesuai jadwal yang telah direncanakan sebelumnya.

c. Hasil

Hasil yang diharapkan terkait pelaksanaan pemeriksaan kesehatan, yaitu:

1) Masyarakat dapat memahami maksud dan tujuan dilakukan pemeriksaan kesehatan ini

2) Masyarakat dapat mengetahui hasil dari pemeriksaan kesehatan pada masing-masing masyarakat

3) Masyarakat dapat memperoleh terapi atau obat sesuai dengan keluhan pada hasil pemeriksaan

4) Masyarakat dapat melakukan konsultasi langsung pada petugas kesehatan yang hadir pada kegiatan tersebut sesuai dengan hasil pemeriksaan yang tlah diterima.

\section{HASIL DAN PEMBAHASAN}

Tabel 1. Hasil Kegiatan Pemeriksaan Kesehatan

\begin{tabular}{|c|l|c|c|c|c|c|}
\hline No & Nama & Umur & Alamat & Jenis Pemeriksaan & Hasil & Diagnosa \\
\hline 1 & Maimun & 47 & leSeuum & Tekanan Darah & $150 / 90 \mathrm{mmHg}$ & Hipertensi \\
\hline 2 & Mutia & 36 & leSeuum & Glukosa & $220 \mathrm{mg} / \mathrm{dL}$ & DM \\
\hline
\end{tabular}




\begin{tabular}{|c|l|c|l|c|c|c|}
\hline 3 & Sri Maulida & 39 & leSeuum & Glukosa & $127 \mathrm{mg} / \mathrm{dL}$ & Normal \\
\hline 4 & Abdullah & 37 & leSeuum & Tekanan Darah & $140 / 90 \mathrm{mmHg}$ & Hipertensi \\
\hline 5 & Devi & 23 & leSeuum & Tekanan Darah & $140 / 90 \mathrm{mmHg}$ & Hipertensi \\
\hline 6 & Zulfan & 34 & leSeuum & Glukosa & $138 \mathrm{mg} / \mathrm{dL}$ & Normal \\
\hline 7 & Nurmala & 43 & leSeuum & Glukosa & $200 \mathrm{mg} / \mathrm{dL}$ & DM \\
\hline 8 & Zuraida & 38 & leSeuum & Tekanan Darah & $150 / 80 \mathrm{mmHg}$ & Hipertensi \\
\hline 9 & Nasriah & 53 & leSeuum & Glukosa & $142 \mathrm{mg} / \mathrm{dL}$ & Normal \\
\hline 10 & Zulkifli & 41 & leSeuum & Tekanan darah & $140 / 100 \mathrm{mmHg}$ & Hipertensi \\
\hline 11 & Taufiq & 30 & leSeuum & Glukosa & $236 \mathrm{mg} / \mathrm{dL}$ & DM \\
\hline 12 & Diana & 32 & leSeuum & Glukosa & $233 \mathrm{mg} / \mathrm{dL}$ & DM \\
\hline 13 & M. yunus & 39 & leSeuum & Tekanan darah & $130 / 90 \mathrm{mmHg}$ & Normal \\
\hline 14 & Yusri & 34 & leSeuum & Glukosa & $295 \mathrm{mg} / \mathrm{dL}$ & DM \\
\hline 15 & Nurhayati & 42 & leSeuum & Glukosa & $217 \mathrm{mg} / \mathrm{dL}$ & DM \\
\hline 16 & Abu Baka & 53 & leSeuum & Glukosa & $210 \mathrm{mg} / \mathrm{dL}$ & DM \\
\hline 17 & Rosmini & 33 & leSeuum & Tekanan darah & $110 / 70 \mathrm{mmHg}$ & Normal \\
\hline 18 & Nurbaiti & 35 & leSeuum & Tekanan darah & $120 / 80 \mathrm{mmHg}$ & Normal \\
\hline 19 & Basri & 46 & leSeuum & Tekanan darah & $140 / 90 \mathrm{mmHg}$ & Hipertensi \\
\hline 20 & Ali & 42 & leSeuum & Glukosa & $189 \mathrm{mg} / \mathrm{dL}$ & Normal \\
\hline 22 & M. Thaib & 48 & leSeuum & Glukosa & $257 \mathrm{mg} / \mathrm{dL}$ & DM \\
\hline 23 & Idris & 49 & leSeuum & Glukosa & $255 \mathrm{mg} / \mathrm{dL}$ & DM \\
\hline
\end{tabular}

Dalam melakukan pengabdian masyarakat ini perlu melengkapi kekuatan yang ada diantara elemen-elemenyang terkait pada giatan ini. Program pengabdian masyarakat kepada masyarakat di Desa le Suum kecamatan Mesjid Raya Kabupaten Aceh Besar dapat diselenggarakan dengan baik dan lancar sesuai dengan rencana kegiatan yang telah disusun, meskipun belum semua masyarakat Desa le Suum memiliki kesadaran untuk hidup sehat. Kegiatan ini mendapatkan sambutan yang sangat baik dari masyarakat desa le Suum, terbukti dengan keaktifan dan kehadiran masyarakat desa untuk mengikuti kegiatan pemeriksaan gratis kesehatan dengan tidak meninggalkan kegiatan sebelum waktu berakhir.

Dimana proses yang berjalan sesuai dengan perencanaan, masyarakat datang dengan tetap menjalankan protokol kesehatan di masa pandemi covid ini diantaranya memakai masker, cuci tangan pakai sabun pada tmpat yang telah disediakan, menjaga jarak dengan membuat barisan antrian, kemudian setiap individu didata identitasnya, lalu msing-masing diberikan kartu untuk mengisi hasil pemeriksaan, selanjutnya dilakukan pemeriksaan Tekanan darah, Glukosa darah dan asam urat, kemudian diberikan terapi atau obat sesuai dengan hasil pemeriksaan dan masyarakat juga dapat berkonsultasi langsung dengan petugas kesehatan yang ikut serta pada kegiatan ini. Dari hasil pemeriksaan pada seluruh masyarakat yang datang pada kegiatan ini yang berjumlah 23 orang, mayoritas didapatkan hasil pemeriksaan tekanan daraah yang menjadi masalah kesehatan dimana sebagian masyarakat tersebut mengalami Hipertensi baik pada usia remaja, dewasa maupun lansia.

Berdasarkan referensi yang tersedia, Hipertensi menjadi salah satu ancaman kesehatan masyarakat karena potensinya yang sangat mampu mengakibatkan kondisi komplikasi seperti stroke, penyakit jantung coroner, dan gagal ginjal. Penegakkan diagnose dapat dilakukan melalui pengukuran tekanan darah. Hipertensi di tandai dengan hasil pengukuran tekanan darah yang menunjukkan tekanan sistolik sebesar $>140 \mathrm{mmHg}$ atau dan tekanan diastolik $>90 \mathrm{mmHg}$.

Nilai normal tekanan darah seseorang dengan ukuran tinggi badan, berat badan, tingkat aktivitas normal dan kesehatan secara umum adalah 120/80 mmHg.Dalam aktivitas sehari-hari, 
tekanan darah normal adalah dengan nilai angka kisaran stabil.Tetapi secara umum, amgka pemeriksaan tekanan darah menurun saat tidur dan meningkat sewaktu aktivitas.

Hipertensi merupakan gejala penyakit yang ditandai dengan peningkatan tekanan darah dalam rangka panjang yang dapat merusak organ-organ target tertentu seperti otak, ginjal, retina, jantung, pembesaran vertikel kiri/bilik kiri, gagal jantung kronik, kerusakan retina mata/kebutaan.

Hipertensi dapat dicegah dengan mengendalikan perilaku beresiko seperti merokok, diet yang tidak sehat, seperti kurang konsumsi sayur dan buah serta konsumsi gula, garam dan lemak berlebihan, obesitas, kurang aktifitas fisik, konsumsi alkohol yang berlebihan dan stress (Kemenkes RI, 2021).
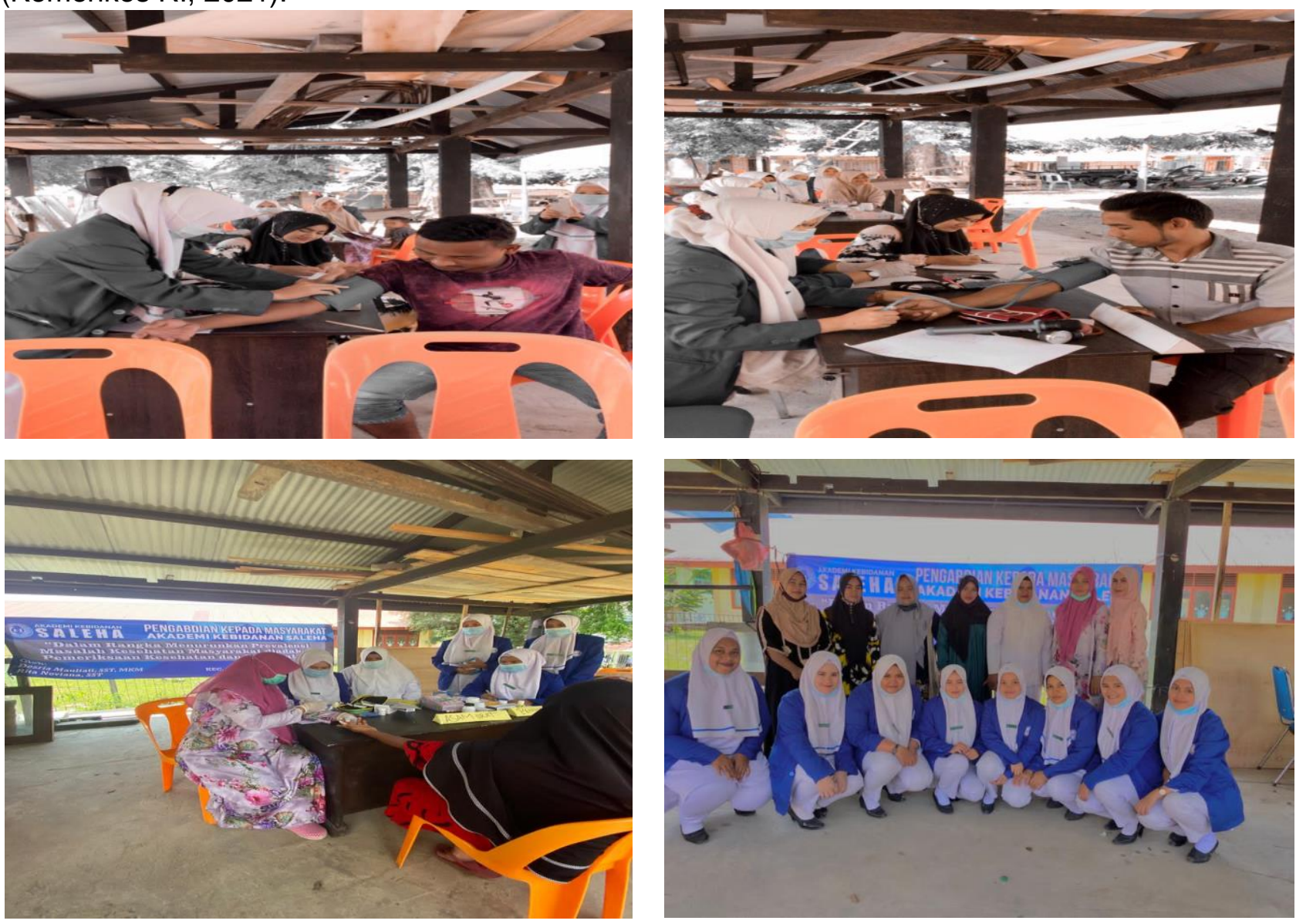

Gambar 1. Dokumentasi Pelaksanaan Pemeriksaan Kesehatan

\section{KESIMPULAN}

Dalam melaksanakan kegiatan pemeriksaan kesehatan gratis pada masyarakat Desa le Seuum dan memberikan pengetahuan tentang cara mencegah hipertensi, gula darah, asam urat, dengan membagi pengetahuan tentang kesehatan terutama pada masa pandemi covid-19 yang rentan terhadap virus berbahaya tersebut apabila kita tidak dapat menghasilkan daya tahan tubuh yang kuat baik itu berasal dari makanan, psikologis dan penyakit penyerta yang dapat memperparah paparan virus corona tersebut, masyarakat Desa le Seuum bisa lebih berhati-hati dalam mengkonsumsi makanan yang terlalu berlebihan, masyarakat juga bisa mengatur pola makan, dan berolahraga untuk mengurangi penyakit yang dialami atau mencegah penyakit tersebut. Karena mencegah lebih baik dari pada mengobati. Mengingat banyaknya masyarakat yang kurang peduli akan kesehatan, maka dengan adanya kegiatan pemeriksaan gratis pada pengabdian masyarakat untuk mengurangi angka mortalitas dan morbiditas yang disebabkan oleh penyakit-penyakit kronik. 
Kesimpulan dari pengabdian ini agar terselenggaranya dengan baik dan lancar sesuai dengan rencana kegiatan yang telah disusun, salah satunya masyarakat tetap mematuhi protokol kesehatan dimasa pandemi covid terkait dengan diadakannya kegiatan pemeriksaan kesehatan dimana terdapat masalah kessehatan yang terjadi yaitu salah satunya masalah hipertensi. Dimana masyarakat dapat mengetahui hasil dari pemeriksaan kesehatan dan dapat melakukan konsultasi langsung pada petugas kesehatan yang hadir pada kegiatan tersebut sesuai dengan hasil pemeriksaan yang telah diterima. kegiatan ini mendapatkan sambutan yang sangat baik dari masyarakat dengan keaktifan dan kehadiran masyarakat untuk mengikuti kegiatan pemeriksaan kesehatan gratis dengan tidak meninggalkan kegiatan sebelum waktu berakhir.

\section{UCAPAN TERIMA KASIH}

Ucapan terima kasih yang sebesar-besarnya kami sampaikan kepada Camat Kecamatan Mesjid Raya Kabupaten Aceh Besar dan juga terima kasih kepada Kepala Desa le Suum beserta perangkat desa, bidan desa, kader desa dan petugas kesehatan lainnya yang telah memberikan izin dan dukungan terhadap pelaksanaan kegiatan ini. Kepada mahasiswa Akbid saleha yang telah ikut serta memberikan dukungan tenaga terhadap pelaksanaan kegiatan. Dan tidak lupa pula terima kasih kepada Akademi Kebidanan Saleha yang telah memberikan dukungan fasilitas terhadap pelaksanaan kegiatan ini sehingga berjalan dengan lancar.

\section{DAFTAR PUSTAKA}

Ahmad, N. (2011). Cara Mencegah dan Mengobati Hipertensi. Jakarta : Rineka Cipta

Kemenkes, R. I. (2021) Pedoman pencegahan dan pengedalian coronavirus Diasease 2021 (Covid-19). Jakarta: Kementerian Kesehatan Republik Indonesia.

Riskesdas Aceh (2021). Revalensi angka kejadian Hipertensi Provindi Aceh. Aceh: Riskesdas Aceh.

Sutanto. (2010). Penyakit modern Hipertensi, stroke, Jakarta, Kolestrol, dan Diabetes. Yogyakarta : CV Andi.

WHO. (2021). Virus corona Menurut WHO dan Virus Corona di Dunia https:2virus-corona-dancirinya-menurut-situs-who

Wijayakusuma, H. (2006). Hipertensi Jakarta : PT Gramedia Pustaka Utama. 